\title{
NOTES
}

\section{SEPARATE REVIEW OF CLAIMS IN MULTIPLE CLAIMS SUITS: APPELLATE JURISDICTION UNDER AMENDED FEDERAL RULE 54(b)*}

APPELIATE jurisdiction in the federal courts is normally limited by statute to the review of final decisions. ${ }^{1}$ In its historic form the final decision rule meant that appeal could be taken only from a decision settling all issues as iv all parties. ${ }^{2}$ But when multiple claims are involved in one suit, trial con-

* Bendix Aviation Corp. v. Glass, 195 F.2d 267 (3d Cir. 1952) ; Flegenheimer v. General Mills, 191 F.2d 237 (2d Cir. 1951).

1. The latest revision of the Judicial Code provides: "The courts of appeals shall have jurisdiction of appeals from all final decisions of the district courts. ..." 28 U.S.C. $\$ 1291$ (Supp. 1952). The jurisdiction of the Supreme Court over state decisions is likewise governed by the final decision rule. 2S U.S.C. $\$ 1257$ (Supp. 1952). For an historical analysis and criticism of the final decision rule, see Crick, The Final Judgmont as a Basis of Appeal, 41 YaLE L.J. 539 (1932).

No satisfactory definition of a final decision can be found. Courts often have said that finality involves the termination of the litigation so that nothing remains but to execute the judgment. See, e.g., Catlin v. United States, 324 U.S. 229, 233 (1945). For an extensive list of various orders held to be final or not final, see 1 OnnI:Gers, Ferersu. Practice 534-44 (1949).

Orders which are not final are termed interlocutory orders and are usually not aprealable. But statutory exceptions have been crcated for orders (1) granting, continuing, modifying, refusing, or dissolving injunctions, or refusing to dissolve or modify injunctions; (2) appointing receivers, or refusing to wind up receiverships; (3) determining the rights and liabilities of the parties to admiralty cases in which appeals from final decrees are allowed; (4) settling rights in civil actions for patent infringemumt which are complete except for accounting. 2S U.S.C. \$ 1292 (Supp. 1952). The purpose of this section is said to be "to allow appeals from orders other than final judgments when they have a final and irreparable effect on the rights of the parties." Jir. Justice Jaclison in Cohen v. Beneficial Loan Corp., 337 U.S. 541, 545 (1949). Other opinions stress the unnecessary delay and expense which might result from inability to aypeal orders covered by $\$ 1292$. See Smith v. Vulcan Iron Works, 165 U.S. 51S, 525 (1597) (decree granting injunction); Russell Box Co. v. Grant Paper Box Co., 179 F.2d 7\$5, 787 (1st Cir. 1950) (patent infringement) ; Stark v. Texas Co., \&8 F.2d 182, 183 (5th Cir. 1937) (admiraity).

The courts of appeals also have jurisdiction to hear interlocutory appeals in banl:ruptcy under Title 11 of the U.S. Code. And, in addition, the prerogative writs may to used in certain cases to review interlocutory orders. Note, SS YALE LJ. 1186, 1183 (1949); Crick, stspra, at 5547.

For judicially-created exceptions, see note 36 infra.

2. United States v. Girault, 11 How. 21, 32 (U.S. 1850); Holcumbe v. MeKusicl, 20 How. 552, 554 (U.S. 1857); Loveland, A ppellate Jurasdictio:i 144 (1911). Cf. Collins v. Míller, 252 U.S. 364,370 (1920.) 
venience may lead to separate disposition of parties and claims. ${ }^{3}$ And delay in obtaining review of such a disposition may cause litigants tunnecessary hardship. ${ }^{4}$ In recognition of this problem, courts for many years have held in some cases that certain claims were sufficiently separable from the rest of the litigation to support independent appeal. 5 And with the adoption of the Federal Rules of Civil Procedure, permitting joinder in one stit of multiple parties and claims which formerly would have required independent actions, ${ }^{0}$ a more flexible concept of finality became imperative. ${ }^{7}$ So Rule 54 (b) was drafted providing that "when more than one claim for relief [was] presented in an action," a district judge could enter a separate judgment "upon a determination of the issues material to a particular claim and all counterclaims arising out of the transaction or occurrence which [was] the subject matter of the claim. ..."8

In an attempt to reconcile the "separate judgment" of Rule 54(b) with the statutory requirement of finality, the Supreme Court held in Recves $v$. Beardall ${ }^{9}$ that judgments disposing of claims arising out of "wholly separate and distinct transactions" were separately appealable. ${ }^{10}$ But lower courts had

3. FED. R. Crv. P. 42(b) provides: "The court in furtherance of convenience or to avoid prejudice may order a separate trial of any claim, cross-claim, counterclaim, or third-party claim, or of any separate issue or of any number of claims, cross-claims, counterclaims, third-party claims, or issues."

4. See Dickinson v. Petroleum Corp., 338 U.S. 507, 511 (1950).

5. See, e.g., United States v. River Rouge Co., 269 U.S. 411 (1926) (decree disposing of claims of several parties in a condemnation action although a new trial was ordered as to one party on a distinct claim) ; Hill v. Chicago \& Evanston R.R., 140 U.S. 52 (1891) (decree dismissing as to several parties although the amount of one item was referred to a master); William v. Morgan, 111 U.S. 684 (1884) (decree fixing compensation to be paid to trustees under a mortgage in a foreclosure action).

6. See Fed. R. Civ. P. 13 (counterclaim and cross-claim) ; Fev. R. Civ, P. 14 (joinder of third parties); FED. R. Civ. P. 18 (joinder of claims and remedies); FED. R. Civ. P. 20 (permissive joinder of parties). For an extensive treatment of the practice in law and equity prior to the Federal Rules, see Dobie, Federal Jurusdiction and Procenuxe 579-783 (1928).

7. See Dickinson v. Petroleum Corp., 338 U.S. 507, 511 (1950); 3 Aloore, Feperdl Practice 3156 (1st ed. 1938).

8. 308 U.S. 732 (1939) (Rules of Civil Procedure, p. 70).

9. 316 U.S. 283 (1942). Plaintiff brought three claims in a single action: (1) on a promissory note executed by respondent's decedent; (2) on a contract between plaintiff and respondent's decedent, whereby the latter agreed not to change her will in return for certain securities and plaintiff's forebearance on the note; (3) for an accounting against a third party who was alleged to hold assets of the respondent's decedent. Reversing tho holding of the Fifth Circuit, the Supreme Court unanimously ruled that, although the other claims had been left pending, a dismissal of the second claim was immediately appealable.

10. "The Rules make it clear that it is 'differing transactions or occurrences, which form the basis of separate units of judicial action." Reeves v. Beardall, 316 U.S. 283, 285 (1942), quoting Judge Clark in Atwater v. North American Coal Corp., 111 F.2d 125, 126 (2d Cir. 1940) (concurring opinion). 
difficulty in applying this test of finality.11 Since the Rules failed to define a "claim," two different theories arose to determine whether an order actually disposed of a separate claim.12 The "pragmatic" approach focused on the factual situations presented to define a claim, 13 whereas the "cause of action" approach looked to the legal theories of the case. ${ }^{14}$ Under the first definition, a separate set of facts constituted a claim which had to be appealed as one unit; $;^{15}$ and under the latter view, separate and distinct claims which were separately appealable could arise out of the same set of facts. ${ }^{10}$ Even if a litigant knew which theory the court would apply, however, neither approach defined its own criteria with sufficient precision to enable the litigant to determine when he had a final and appealable claim. ${ }^{17}$

The confusion among the courts after the Recers case placed litigants in a dilemma. Should they seek review they might be dismissed for lack of finality after having prepared their case on the merits. Yet once a judgment was entered on an appealable claim, time for taking an appeal began to run. ${ }^{28}$ Thus, an inaccurate guess as to appealability might result in a denial of the right to review on that claim. ${ }^{19}$ To protect themselves against such an eventuality, litigants were forced to take precautionary appeals, which might prove fruitless and unnecessary. ${ }^{20}$

To eliminate the confusion about when appeal could be taken, Rule 54(b) was amended, effective in 1948. All criteria defining the scope of a final

11. Compare Wright v. Gibson, 128 F.2d $\$ 65$ (9th Cir. 1942), arith Hanney v. Franlslin Fire Ins. Co. of Philadelphia, 142 F.2d S64 (9th Cir. 1944); and Collins v. MetroGoldwyn Pictures Corp., 106 F.2d 83 (2d Cir. 1939), with Clarl: v. Taylor, 163 F.2d 940 (2d Cir. 1947). See Comments, 47 CoL L. Rev. 239 (1947) ; 47 MIrer. L. Rev. 233 (1948).

12. See Note, 56 Y ALE L.J. 141, 143 (1946).

13. E.g., Petrol Corp. v. Petroleum Heat \& Power Co., 162 F.2d 327, 329 (2d Cir. 1947) ; Audi Vision, Inc. v. R.C.A. Mlfg. Co., 136 F.2d 621 (2d Cir. 1943); Original Ballet Russe v. Ballet Theatre, 133 F.2d 187 (2d Cir. 1943).

14. E.g., Zaratti S.S. Co. v. Park Bridge Corp., 154 F.2d 377 (2d Cir. 1946); Hanney v. Franklin Fire Ins. Co. of Philadelphia, 142 F.2d E64 (9th Cir. 1944); Zallind v. Scheinman, 139 F.2d 895 (2d Cir. 1943).

15. Clark v. Taylor, 163 F.2d 940, 942 (2d Cir. 1947); Petrol Corp. v. Petroleum Heat \& Power Co., 162 F.2d 327, 329 (2d Cir. 1947).

16. Hanney v. Franklin Fire Ins. Co. of Philadelphia, 142 F.2d \&Gt (9th Cir. 1944). See Clark v. Taylor, 163 F.2d 940, 949 (2d Cir. 1947) (dissenting opinion).

17. "[D]ecisions as to the extent of a 'claim' or a "cause of action' or a 'trancaction" must necessarily be directed to the facts in issue in a particular case and cannot be safely generalized into rigid rules applicable to other factual situations. . ." Judge Clarls in Collins v. Metro Goldwyn Pictures Corp., 105 F.2d \&3, \$6 (2d Cir. 1939) (concurring opinion). See Note, 56 Yare L.J. 141, 145 (1946).

18. See Dickinson v. Petroleum Corp., 338 U.S. 507 (1950).

19. Ibid.

20. Anvisory Comantrtee's Note to Fed. R. Civ. P. 54 (b), 28 U.S.C., following \$ 723c (1946); Mfoore, Coararentary on the U.S. Judictal Cons 514-15 (1949); Comment, 47 MICH. L. REv. 233, 237 (1948); Note, 56 YALE L.J. 141, 148 (1946). 
judgment were deleted. Instead, the Rule now provides that a trial judge may enter a final judgment disposing of "one or more but less than all" of the claims in a multiple claims suit upon "an express determination that there is no just reason for delay and an express direction for the entry of judgment." Without these specific findings, time for appealing such claims does not run. And no order ${ }^{22}$ separately disposing of a claim is appealable without such findings, even though a similar order would have been heard under the old Rule. ${ }^{23}$ By this device it was hoped that a simple, definite, and workable test of finality had been established which would both reduce the number of appeals from multiple claims suits and protect litigants from inadvertently losing their right of appeal. At the same time the discretion given the trial judge would permit appeal in the infrequent hardship case. ${ }^{24}$

Where an order separately disposes of at least one of the claims in a multiple claims suit, the need for precautionary appeals has been eliminated, because Rule 54(b) specifically provides that such an order is not final without the determination of the trial judge. But the possibility remains that where a litigant has taken an appeal on the basis of the trial judge's determination, he may still be dismissed by the appellate court for lack of finality. Two interpretations of the new 54(b) have been advanced. In Flegenhicimer $v$.

21. In its present amended form, Rule 54(b) reads as follows: "When more than one claim for relief is presented in an action, whether as a claim, counterclaim, crossclaim, or third-party claim, the court may direct the entry of a final judgment upon one or more but less than all of the claims only upon an express determination that there is no just reason for delay and upon an express direction for the entry of judgment. In the absence of such determination. and direction, any order or other form of decision, however designated, which adjudicates less than all the claims shall not terminate the action as to any of the claims, and the order or other form of decision is subject to revision at any time before the entry of judgment adjudicating all the claims." FED. R. Crv. P. 54(b).

22. Interlocutory orders appealable by statute, see note 1 supros, are not included under Rule 54(b). Cutting Room Appliance Corp. v. Empire Cutting Mach. Co., 186 F.2d 997 (2d Cir. 1951) ; Moore, Federal Rules Pauphlet 252 (1951). Contra: Packard Motor Car Co. v. Gem Mfg. Co., 187 F.2d 65 (7th Cir. 1951).

But judicial exception to the final decision rule, see note 36 infra, may in some instances come under 54(b). For discussion of the applicability of $54(\mathrm{~b})$ to such situations, see Moore, Federal Rules Pamphlet 253-6 (1951).

Whether a case actually involves multiple claims so as to come within the provisions of 54(b) may also cause difficulty. See General Time Corp. v. Padua Alarm Systems, Inc., 199 F.2d 351 (2d Cir. 1952).

23. Lyman v. Remington Rand, Inc., 188 F.2d 306 (2d Cir. 1951); David v. District of Columbia, 187 F.2d 204 (D.C. Cir. 1950). Moore, Commentary on teE U.S. Judiciat. CODE 516 (1949).

24. Advisory Comanittee's Note to FED. R. Civ. P. 54(b) 28 U.S.C., following $\$$ 723c (1946). It has been asserted that mandamus will be available in cases of flagrant abuse of discretion by the trial judge in refusing to make a determination. Moons, ConsMENTaRy on the U.S. Judicial Code 518 (1949). Cf. Winsor v. Daumit, 179 F.2d 475, 478 (7th Cir. 1950). 
General Mills, ${ }^{25}$ the Second Circuit held that the determination of the trial judge could not make final and appealable an order which would not have been final prior to the amendment. ${ }^{20}$ Accordingly, that court would still have to determine its own jurisdiction on appeal by the same confusing tests of finality that had plagued litigants under original $54(\mathrm{~b})$. On the other hand, in Bendix Aviation Corp. v. Glass, ${ }^{27}$ the Third Circuit, sitting cn bane, ${ }^{23}$ held that the trial judge's determination made appealable an order dismissing a claim without disposing of a compulsory counterclaim-an order which clearly would not have been appealable under the original Rule. So in that circuit, whenever an order separately disposes of either a claim or counterclaim, the litigant, having secured the determination of the trial judge, is assured of having his appeal heard on the merits.

The rationale of the Flegenheimer approach, as extended by two dissenting judges in Bendix, ${ }^{29}$ is that to allow appeals now which would not have been heard prior to the amendment would change the established meaning of

25. 191 F.2d 237 (2d Cir. 1951), 65 HARv. L. Rev. 1245 (1952), 36 Mmm. I. Rer. 403 (1952). Originally, action in contract had been brought against defendant Canadian corporation, plaintiff Flegenheimer attaching property which he asserted belonged to defendant. General Miills then had been allowed to intervene and set up a claim of ownership to the goods attached. And upon dismissal of its claim, General Miflls had sought to appeal; but the dismissal had been held to be interlocutory because no express determination had been made under 54(b). Flegenheimer v. Manitoba Sugar Ltd., 178 F.2d 742 (2d Cir. 1950). After appellant had secured the proper determination, Judge Learned Hand held, in the instant case, that the order would still not be reviewed because historically such an order was not final. It is questionable, however, whether the order would not have been appealable under original 54(b). See Lopinsly v. Hertz DriveUr-Self Systems, 194 F.2d 422, 429 (2d Cir. 1951) (concurring opinion).

26. The Second Circuit is sharply split on this problem. Compare Judge Franls's view in Pabellon v. Grace Line, 191 F.2d 169, 176 (2d Cir. 1951) (coneurring opinion), cert. denied sub nom. Coston Supply Co. v. Pabellon, 342 U.S. \$93 (1951), zrith Judge Clark's view in Lopinsky v. Hertz Drive-Ur-Self Systems, 194 F.2d 422, 424 (2d Cir. 1951) (concurring opinion).

27. 195 F2d 267 (3d Cir. 1952), 65 Hasv. L. Rev. 1245. The action was one for specific performance on an employment contract. It asked that defendant be required to execute a patent application on defendant's invention to which plaintiff was entitled by terms of the contract, and that the defendant be restrained from dealing with the invention as his own. Defendant counterclaimed, asserting that the assignment of his invention to plaintiff was made under circumstances entitling him to compensation. Thereafter the defendant moved for dismissal of the original complaint on the ground that, since the institution of the suit, he had complied with the contract and filed the patent application in the form requested by plaintiff. The motion was granted with the trial judge making the determination required by Rule 54(b).

28. An original hearing held the order non-appealable. See 20 U.S.L. WeEr 2106 (3d Cir. Sept. 6, 1951), 100 U. of PA. L. REv. 451. This opinion vas withdrawn and a rehearing held en banc.

29. While Judges Hastie and Kalodner argued that the order could be heard under $\S$ 1292 , see note 1 stipra, as an order denying an injunction; they felt it should not te heard under Kule 54(b) following the Flegenheiner doctrine. Thus, although their opinion is actually a concurrence, it is referred to throughout this note as a dissent. 
"final decision." This would materially alter the jurisdiction of the courts of appeals-a result beyond the rule-making power of the Supreme Court. ${ }^{\text {go }}$ Furthermore, fear is expressed that the Bendix holding would contravene the historic policy against interlocutory appeals ${ }^{31}$-a policy based on the conservation of judicial energy ${ }^{32}$ and the avoidance of unnecessary delay and cost to litigants. ${ }^{33}$ In the view of the Bendix minority, appeals shotild encompass a sufficient quantum of litigation to forestall multiple review of the same facts. Such was the rule prior to the Reeves case, they argue; that case merely crystallized the "separate transaction" as the proper unit for judicial review. ${ }^{34}$ Since a claim and compulsory counterclaim, as in Bendix, patently involve overlapping facts, only an order disposing of both claims can be considered final.

Judicial history casts doubt on the immutability of "final decision." Originally, a final decision required the termination of the entire litigation. ${ }^{36}$ Yet not only were judicial exceptions created before the Federal Rules, ${ }^{30}$ but original 54(b), as interpreted in the Reeves case, itself changed prior concepts of final-

30. "[T] $]$ he act of June 19, 1934, 48 STAT. 1064, 28 U.S.C. 723b, authorizing this court to prescribe rules of procedure in civil actions gave it no authority to modify, abridge or enlarge substantive rights of litigants or to enlarge or diminish the jurisdiction of the federal courts." Mr. Justice Stone in United States v. Sherwood, 312 U.S. 584, 590 (1941).

31. Bendix Aviation Corp. v. Glass, 195 F.2d 267, 278 (3d Cir. 1952) (concurring opinion). See Cobbledick v. United States, 309 U.S. 323, 325 (1940). Crick, The Final Judgment as a Basis of Appeal, 41 YALE L.J. 539, 551 (1932), points out that carly decisions merely asserted the rule without giving any justification for it. As the busincss of the courts increased at a rapid rate, the final decision rule proved a ready made devicc for discouraging excessive appeals and came to be justified in these terms.

In the New York state courts, appeals may be taken as of right from almost all interlocutory orders. N.Y. Crv. Prac. Acr $\S 609$. Judge Clark believes this may account for the fact that so many final decision cases arise in the Second Circuit. Zalkind v. Scheinman, 139 F.2d 895, 907 n.5 (2d Cir. 1943) (dissenting opinion). This state practice may result in a preference by litigants for the federal courts. Harper, Civil Practice it the Federal Courts 81, in Practising Law Institute, Trial Practice (1946).

32. "[M]any mistakes, apparently important at the time, will be seen to be trivial from the perspective of a final disposition of the case. ..." Perkins v. Endicott Johnson Corp., 128 F.2d 208, 212 (2d Cir. 1942), aff'd, 317 U.S. 501 (1943). Sec also Catlin v. United States, 324 U.S. 229, 234 (1945).

33. Sec Cobbledick v. United States, 309 U.S. 323, 325 (1940) ; Forgay v. Conrad, 6 How. 201, 205 (U.S. 1848); Canter v. American Ins. Co., 3 Pet. 307, 318 (U.S. 1830).

34. Bendix Aviation Corp. v. Glass, 195 F.2d 267, 278-80 (3d Cir. 1952) (concurring opinion). See note 37 infra.

35. Collins v. Miller, 252 U.S. 364, 370 (1920); Holcombe v. McKusick, 20 How. 552, 554 (U.S. 1857) ; United States v. Girault, 20 How. 21, 32 (U.S. 1850).

36. Three classes of judicial exception to the final decision rule have evolved:

(1) The rule in Forgay v. Conrad, 6 How. 201 (U.S. 1848) (decree disposing of property which the successful party was entitled to have carried into execution immediately is final, although the judgment also provided for an accounting). Sec Radio 
ity. ${ }^{37}$ Nor was the policy against piecemeal review applied as strictly, prior to the Federal Rules, as the Bcndix minority imply. Since Bendix involved an equitable claim for specific performance and a legal cuunterclaim for damages, plaintiff could have objected to interposition of the counterclain. In such instance defendant would have been forced to bring his cuunterclaim in an independent action, which would have been separately appralable..$^{39}$ Moreover, even under original 54(b), orders disposing of cross-claims, intervenor's claims and third-party claims were separately appealable although

Station WOW v. Johnson, 326 U.S. 120 (1945); Thompson v. Dean, 7 Wall. 342 (U.S. 1869); Kasishke v. Baker, 144 F.2d 384 (10th Cir. 1944).

(2) The "offshoot" rule applying to collateral orders. See Trustees v. Greenough, 105 U.S. 527 (18S1) (order directing costs to be paid out of a fund in the hands of the court) ; Swift \& Co. Packers v. Compania Colombiana Del Caribe, 339 U.S. 684 (1950) (order vacating an attachment in admiralty); Cohen v. Beneficial Industrial Loan Corp., 337 U.S. 541 (1949) (order denying a corporation's motion that the plaintiff in a stod:holder's derivative suit be required, pursuant to state statute, to give security for reasonable expenses of the defendant in connection with the action).

(3) The separate order in multiple-party suits. See note 5 supro.

In carving out exceptions to the final decision rule, courts have been careful to point out that they are not making interlocutory orders appealable. Rather they assert that the order in question is separable from or collateral to the rest of the litigation so that the order in question is a final decision. Scc Cohen v. Beneficial Industrial Loan Corp., 337 U.S. 541, 546 (1949).

37. There were several possibilities for joinder of claims arising out of different transactions, even under pre-Federal Rules practice. Under common law pleading, when applicable in the federal courts, claims falling within the legal limits of a certain form of action could be joined although based on widely separated groups of facts. CLArs, Cosz Pleadirg 436 (2d ed. 1947). Equity Rule 26, 226 U.S. 655 (1912), provided that a plaintiff could join as many equitable causes of action against a defendant as he might have. See Dobie, Federal Practice and Procedune 681-3 (1928). And under Equity Rule 30, 226 U.S. 657 (1912), a defendant could set up in his answer any equitable counterclaim he might have against the plaintiff although arising out of $a$ different transaction from the subject matter of the suit. See American Mfills Co. v. American Surety Co., 260 U.S. 360, 365 (1922) ; DoBIE, stipra, at 701-07. In none of these situations was a decision disposing of less than all the claims by one party against another final and appealable. Collins v. Miller, 252 U.S. 364, 370 (1920) ; Sheppy v. Stevens, 200 Fed. 940 (2d Cir. 1912) ; Mioore, Federal Rules Pampeleter 247 (1951). But sce Note, 49 Yale L.J. 1476, 1480 and $n .25$ (1940).

To the extent that Reeves $v$. Beardall extended the separate transaction test to cover such situations, it changed prior decisional law. The Riter Rouge type of exception, supra note 5, while based on a separate transaction, applied only where there were multiple parties and not to cases where there was but a single defendant. Ex fartc National Enameling Co., 201 U.S. 156, 165 (1905); Sheppy v. Stevens, 200 Fed. 946, 943 (2d Cir. 1912); MLoore, Feneral Rules Paxiphlet 248 (1951).

38. There was no compulsory joinder of legal counterclaims in an equitable action although both claims arose from a single transaction; otherwise the parties would be deprived of their right to jury trial on the legal claim. American Afills Co. v. Ameriean Surety Co. 260 U.S. $360,364-5$ (1922).

Similar rules applied to other situations. Legal claims could not be joined unless they sounded within the same common law form of action. Philips \& Colby Construction Co. 
arising out of the same set of facts as the principal claim and involving multiple review..$^{38}$

The view of the Bendix court that amended Rule 54(b) can and does change the content of the final decision ${ }^{40}$ thus seems historically acceptable. ${ }^{41}$ But even if the Flegenheimer view of finality is rejected in favor of Bcndix, the problem of defining a claim remains. Since Rule 54(b) expressly states that an order must dispose of at least one claim, appellate courts appear bound to dismiss any appeal which does not satisfy this requirement. ${ }^{42}$ In practice, recent decisions have ignored the problem of whether or not an order disposed of a claim. In Boston Medical Supply Co. v. Lea \& Febiger, ${ }^{40}$ the First Circuit held that the trial judge's finding of finality made appealable an order dismissing one of several defendants jointly liable. And in a similar situation in Lopinsky v. Hertz Drive-Ur-Self Systems, ${ }^{44}$ a Second Circuit

v. Seymour, 91 U.S. 646, 654 (1875) ; Garland v. Davis, 4 How. 131 (U.S. 1846). Exceptions were made in allowing the joinder of debt and detinue, and trover and case. See Clark, CODE Pleading 436 and n.4 (2d ed. 1947). And legal and equitable claims could not be joined in a single suit. Scott v. Nealy, 140 U.S. 106, 111 (1891); Bemunctt v. Butterworth, 11 How. 668, 708 (U.S. 1850).

39. See, e.g., Dickinson v. Petroleum Corp., 338 U.S. 507 (1950) (intervenor's claim); New Orieans Public Belt R.R. v. Wallace, 173 F.2d 145 (5th Cir. 1949) (cross-claim) ; Brown v. Cranston, 132 F.2d 631 (2d Cir. 1942) (third-party claim).

40. The Bendix majority argued that procedural rules necessarily affect the number and kinds of appeals going up to the appellate courts; and when such rules change, the impact of the jurisdictional statute must also change. $C f$. Lopinsky v. Hertz Drive-Ur-Self Systems, 194 F.2d 422, 424 (2d Cir. 1951) (concurring opinion). Moreover, the Bendix majority point out that the negative effect of Rule 54(b) in prohibiting the appeal of an order lacking the determination of the trial judge restricts jurisdiction as much as the positive effect would expand it. But see Republic of China v. American Express Co., 190 F.2d 334, 338-9 (2d Cir. 1951).

41. The Bendix position is also taken by Professor Moore, who says, "The Rule does not attempt to modify or supersede the appellate jurisdiction statutes. Their broad outlines remain. Their content has always been supplied by judicial decisions, and if the Supreme Court can by judicial decisions define finality within the meaning of those statutes, as admittedly it has done and can do, then it has the power by rule, which has the force of statute, to define finality for a limited situation-where an action involves multiple claims." Moore, Comanentary on the U.S. Judicial Code 516-17 (1949). For Judge Frank's reply to this argument, see Pabellon v. Grace Line, 191 F.2d 169, 178 (2d Cir.) (concurring opinion), cert. denied sub nom. Coston Supply Co. v. Pabellon, 342 U.S. 893 (1951).

42. See Pabellon v. Grace Line, 191 F.2d 169, 174 (2d Cir.), cert. denied sub nom. Coston Supply Co. v. Pabellon, 342 U.S. 893 (1951).

43. 195 F.2d 853 (1st Cir. 1952). Plaintiff brought an action for treble damages against several defendants for conspiracy under the Clayton Act. The order dismissing one of those defendants on jurisdictional grounds was held appealable.

44. 194 F.2d 422 (2d Cir. 1951). In Tauzin v. Saint Paul Mercury Indemnity Co., 195 F.2d 233 (5th Cir. 1952), appeal was dismissed for lack of finality in this situation. There is no indication, however, whether the trial judge had made a determination under Rule 54(b). 
panel, different from that in Flcgenhcimner, permitted appeal. Regardless of whether a "pragmatic" or "cause of action" theory of claim be employed, however, an order such as this does not dispose of even a single claim. As Although the result reached seems desirable, ${ }^{40}$ the use of the trial judge's determination to justify hearing such an appeal seems a misapplication of the Rule as now written.

But appellate review of whether an order below disposed of a "claim" within the meaning of 54(b) may easily lead to as much uncertainty and confusion as does the problem of finality under Flegenhcinucr.it The old clash between the "cause of action" and "pragmatic" theories under the rule may be perpetuated. 48 And the benefits of Bendix may then be limited to the claim-counterclaim situation, where the "claim" problem does not arise. The litigant, caught in a semantic jungle, may still have to prepare his brief and argument on the merits with little idea whether or not he will be heard.

One means of eliminating present uncertainty as to whether an appsllate court will hear an appeal under 54 (b) might be to make conclusive the determination by the trial judge that there is an appealable clasim. ${ }^{39}$ Although the Boston Medical and Lopinsky courts have in effect reached this result by ignoring the issue of whether the order in question disposed of a claim, the litigant now has no assurance of such treatment should the "claim" issue actually be raised. Consequently, a change in the Rule or jurisdictional

45. Atwater v. North American Coal Corp., 111 F.2d 125, 126 (2d Cir. 1940) (concurring opinion) ("pragmatic" theory) ; Zarati S.S. Co. v. Park Bridge Corp., 154 F2d 377, 379 (2d Cir. 1946) ("cause of action" theory). See Hunteman v. New Orleans Pub. Serv., 119 F.2d 465 (5th Cir. 1941). And see Reeves v. Beardall, 316 U.S. 233, 286 (1942).

46. For example, if an order wrongfully dismissing the only solvent defendant of several jointly liable is not immediately appealable, the plaintiff may have to stand the burden of a long and costly trial resulting in a vorthless verdict before being able to obtain redress. See Pabellon v. Grace Line, 191 F.2d 169, 179 (2d Cir.) (concurring opinion), cert. denied sıb nom. Coston Supply Co. v. Pabellon, 342 U. S. $\$ 93$ (1951); Audi Vision, Inc. v. R.C.A. Mfg. Co., 136 F.2d 621, 626 n.3 (2d Cir. 1943) (coneurring opinion).

47. Other difficulties may arise under present $54(\mathrm{~b})$ in distinguishing batween counterclaims and defenses. See Libbey-Owens-Ford Glass Co. v. Sylvania Industrial Corp., 154 F.2d 814 (2d Cir.), cert. denicd, 328 U.S. 859 (1946); Clans, Cone Plendrita 640-1 (2d ed. 1947). For a discussion of existing confusion as to whether liability is "joint," see Comment, 47 CoL. L. REv. 239, 249 (1947).

45. See page 265 supra.

49. Whenever all the issues as against all the parties have bren decidcd, appeal of right without the trial judge's determination would obtain, as now, under $\$ 1291$. Ses note 1 supra. Any other decision would require the determination of the trial judge as is now required under Rule 54(b). A possible exception might be made for interlocutory orders now appealable by statute and by judicial exception to the final decision rule, based on the possibility of irreparable harm. See note 22 sufro. In all other cases, discretion should rest with the trial judge. 
statutes ${ }^{50}$ seems desirable in order to eliminate the Flegenheimer approach and to remove the real possibility of Boston Medical and Lopinsky being treated as abusive of present 54 (b). Furthermore, such a provision might also require the trial judge to find that no further litigation would be necessary for the judgment to become effective. ${ }^{51}$ If the latter finding were left subject to review, appellate courts could preserve the policy against interlocutory appeals ${ }^{62}$-a policy which, although raising problems similar to those under 54(b), has been excluded from the scope of this Note.

Statutory or rule changes along the lines suggested might provide a workable device for allowing appeals without interference from abstract jurisdictional fetters. ${ }^{53}$ Once the trial judge, familiar with the facts, had determined that an appeal could and should be heard, ${ }^{54}$ the litigant would be assured of having his case heard on the merits with a minimum of cost and delay. The success of such a proposal would depend upon the wise exercise of discretion by the trial judge. Although excessive appeals might be permitted, the potential advantages of the scheme warrant its trial. Should the result be in fact to overburden the appellate courts, an alternative arrangement might be substituted to give the courts of appeals discretion to deny review even where the trial judge had determined that an appeal should be heard. But, in that situation, provision should be made for the appellate court to determine all jurisdictional questions prior to the preparation of the case on the merits.

50. Although the adoption of such a rule would seem within the rule-making power of the Supreme Court, a statutory enactment would resolve all the doubts which have plagued interpreters of Rule 54(b).

51. Cf. Catlin v. United States, 324 U.S. 229, 233 (1945).

52. There have been proposals recently for permitting interlocutory orders to be heard. Judge Frank would give the courts of appeals power to hear such appeals at their discretion, upon the motion of aggrieved litigants. See Pabellon v. Grace Line, 191 F.2d 169, 176 (2d Cir.) (concurring opinion), cert. denied stb nom. Coston Supply Co. v. Pabellon, 342 U.S. 893 (1951). See also Note, 58 Y ALE L.J. 1186, 1189 (1949).

Professor Moore would allow the district judges to certify interlocutory questions, which the appellate courts might hear at their discretion. Moore \& Vestal, Prescill and Potential Role of Certification in Federal Appellate Procedure, 35 VA. L. REv. 1, 7, 45 (1949).

53. Crick, The Final Judgment as a Basis of Appeal, 41 YALE L.J. 539, 558 (1932), speaks of the final decision rule as "a labor saving device which causes more labor than it saves," because of the difficulty in determining what constitutes a final decision. Cf. Pabellon v. Grace Line, 191 F.2d 169, 179 (2d Cir.) (concurring opinion), cert. denied sub nom. Coston Supply Co. v. Pabelion, 342 U.S. 893 (1951).

54. Cf. Judge Clark in Lopinsky v. Hertz Drive-Ur-Self Systems, 194 F.2d 422, 429 (2d Cir. 1951) (concurring opinion).

55. Litigants might prepare short petitions asking for review, provided the trial judge had determined that appeal might be taken. Like petitions for certiorari, these would then be granted or denied before the appeal is heard. Should unreasonable denial by the trial judge of the right to seek such review become a major problem, the appellate courts might be allowed full discretion to hear appeals merely on the motion of the litigants. Sec note 52 supra. 